\title{
Prosecutor's Supervision of Human Rights Observance in the Republic of Kazakhstan
}

\section{Bainur Baigeldi}

\author{
Master's Student of the Concordia University, St. Paul, MN, USA, Office of the Prosecutor General of the \\ Republic of Kazakhstan, Deputy Chairman of the Committee
}

\author{
Doi:10.5901/mjss.2015.v6n6p217
}

\begin{abstract}
In this article the author describes the activities of the Prosecutor's Office in the Republic of Kazakhstan, which on behalf of the state exercises the highest supervision of exact and uniform application of laws, decrees of the President of the Republic of Kazakhstan and other regulatory legal acts on the territory of the Republic, as well as of the lawfulness of pre-trial proceedings, operational investigative activities, administrative and executive production. The author provides an analysis of statistical data on criminal offenses in the Republic of Kazakhstan identifies crime trends in Kazakhstan and gives criminological characteristics. As a result of research the author formulates theoretical principles and recommendations for improving the current legislation and practice, which regulate the activities of the Prosecutor's Office in the Republic of Kazakhstan.
\end{abstract}

Keywords: attorney, law, pre-trial proceedings, operational investigative activity

\section{Introduction}

Observance of human rights in the modern world, amid the globalization of crime is acquiring an ever-increasing importance and relevance, especially in the CIS countries, where the legal system is forming, improving, but is still far from European standards for all positions, including law enforcement agencies, in particular, the prosecutor's supervision.

Acquiring the state sovereignty is accompanied by reassessment of priorities and values enshrined in the Constitution of the Republic of Kazakhstan, "the highest value of which is a person, his life, rights and freedoms (The Constitution, 1995).

In the system of legal protection of human and citizen rights, of paramount importance is the protection of an individual's interests by state authorities and public persons, law enforcement agencies, and in particular, by the prosecutor's office of the Republic of Kazakhstan, which exercises the highest supervision of exact and uniform application of laws, decrees of the President of the Republic of Kazakhstan and other regulatory legal acts on the territory of the Republic, the lawfulness of pre-trial proceedings, investigative activities, administrative and executive proceedings, as well as identifying and eliminating any breaches of legality, disputing the laws and other legal acts that contravene the Constitution and the laws of the Republic, representing the interests of the state in a court of law in cases, manner and within the limits prescribed by the law and conducting criminal prosecutions (the Republic's law "On the Prosecutor's Office", 1995).

The work of law enforcement agencies is acquiring a largely new content in connection with the reassessment of priorities in the state and society, as well as the state's recognition of a person and their rights and freedoms as the highest value. Their particular importance as bodies whose activities are aimed at protecting the State's constitutional basis, the legitimacy, the citizens' rights and freedoms, public order and public security, combating crime, necessitates the development of a modern concept of their activities, including the system of legislative control of their formation and functioning (Solomatina, 2004).

\section{Literature Review}

Current issues of prosecutor's supervision are reflected in the research of the leading domestic and foreign legal scholars. Among recent dissertations on the issues of prosecutor's supervision the following ones should be mentioned.

N.N. Karpov's dissertation was the first logically completed, individual monographic study that solved a major problem associated with the development of the author's approach and evidence-based recommendations for resolving the problems of prosecutor's office activity which ensures lawfulness in the sphere of military service (Karpov, 2012). The above mentioned study systematically discloses legal, philosophical, sociological and ethical positions, based on 
historical and retrospective and comparative-legal analysis of national and foreign legislation and enforcement of Constitution of Russian Federation in the sphere of legal relations.

Y.N. Turygin carried out a complex monographic study devoted to the interaction between the bodies and agencies of the prosecutor's office of the Russian Federation and non-governmental human rights organizations, which defines the concept and legal status of non-governmental human rights organizations, the theoretical, legal and organizational bases of the prosecutor's office cooperation with such organizations in the sphere of protecting human and civil rights and freedoms (Turygin, 2012).

The uniqueness of T.Y. Safonova's dissertation is predetermined by the creation of the author's original vision of the emergence and development of the modern state of the constitutional and legal status, of the key problems and immediate prospects of constitutional and legal regulation of the prosecutor's office activity in Russia. Particularly, the author was the first to carry out, at a monographic level, a systematic analysis of constitutional and legal regulation of the prosecutor's office activities in the Russian Federation as a state body with a special status (Safonova, 2011)

In his research A.N. Uryvaev suggests the author's concept of constitutional and legal regime of human rights activities of the prosecutor's office in the Russian Federation, including its place in the system of separation of power, along with the mechanism which enables the prosecutor's office to ensure constitutional civil rights and freedoms. The author clarifies the place of human rights activity of the prosecutor's office in the state mechanism as well as the amount and scope of the functions of the prosecutor's office in terms of protection of human rights and freedoms. The dissertation suggests a number of changes and additions to the existing Russian legislation on the prosecutor's office which are related to its activities aimed at the protection of civil rights (Uryvaev, 2009).

The academic value of A.M. Dzhafarov's studies lies in that it offers the author's concept of the basic directions of reforming the prosecutor's office of the Azerbaijan Republic on the basis of the international legal principles of the Prosecutor's Office organization and activity in a democratic state. The dissertation represents the first comprehensive monographic research in the domestic legal science and carries out a systematic analysis of EC regulations in terms of organizing the prosecutor's supervision. On this basis the author defines the basic principles of prosecution activity derived from the Committee of Ministers recommendations and the EC Parliamentary Assembly; he singles out supervisory (monitoring) procedural, human rights and other functions of the prosecutor's office, as stipulated in the EC documents, and the classification of these functions is made. The dissertation studies the experience of legislative regulation of the prosecution concept in EC Member States and provides their classification based on several criteria, as well as demonstrating the multiplicity of specific solutions on issues under consideration within EC documents and others (Dzhafarov, 2008).

In his dissertation research D.A. Gonibesov comprehensively covers the issues of organization and activity of the prosecutor's office in the sphere of supervising the compliance with human and civil rights and freedoms in terms of the legal status of prosecution authorities and prosecutors. The problem analysis shows that due to the lack of academic development of this sphere of the prosecutor's office activity, of primary relevance remains the issue of specific features and content of the prosecutor's supervision of observing human rights and freedoms, as well as the prospects of its development (Gonibesov, 2007).

We can view R.V. Sharov's dissertation as making a considerable contribution to the development of prosecutor's supervision. He makes a combination of principal findings and proposals revealing the theoretical assumptions of the prosecutor's supervision of enforcement of laws which restrict human and civil rights and freedoms. The significance of this study is predetermined by the fact that the elaborated conclusions and regulations refer to one of the prosecutor's office principal activities, which has yet not been adequately covered in legal literature, as well as the opportunity of using its theoretical assumptions and conclusions in further academic development of this problem. A number of suggestions and recommendations contained in the dissertation are aimed at improving the existing legislation. Separate conceptual provisions of the work can be taken into account by law enforcement authorities in their practice, etc. (Sharov, 2006).

\section{Materials and Methods}

\subsection{Research methodology}

The methodological basis of the research is represented by the following methods: a universal dialectical method of learning about the general laws and categories of nature, society and the state; general scientific methods such as analysis and synthesis, induction and deduction, as well as historical and logical methods; specific scientific methods system analysis, logical, comparative, statistical methods and others.

The empirical base of the scientific work consists of data collected by the authors during the research while 
working in the prosecutor's office, using the method of expert assessments in relation to the subject of research as well as during the study of the legal precedents for cases of this category. The author analyzed statistical data of the General Prosecutor's Office of the Republic of Kazakhstan in respect of the registered crimes and results of the criminal prosecuting authorities operation for the period 2010-2015 by major categories of crimes.

The theoretical basis of the study is represented by scientific works on criminal law, criminal procedures, prosecutor's supervision, criminal science, general theory of law, philosophy, sociology, psychology and other fields of science.

\section{Results and Discussion}

\subsection{Prosecutorial supervision of crime in the Republic of Kazakhstan for the past five years (from 2010 to 2015).}

According to statistics of the General Prosecutor's Office of the Republic of Kazakhstan as a whole, the following information is provided about criminal cases in 2014: the number of crimes, whose criminal cases were in production during the reporting period -377,330; the number of crimes registered during the reporting period -341,291; the number of crimes whose cases were completed in the reporting period -107,304; the number of crimes whose cases were taken to court in the reporting period - 59,532; the number of crimes, whose criminal cases were terminated for nonrehabilitation grounds $-47,772$; the number of crimes, whose criminal cases were terminated with the removal from the register - 33,291; including due to the absence of elements and evidence of a crime (p.1.2 ch.1 art.37 of Code of Criminal Procedure) - 32,798; on which the decisions to initiate proceedings were canceled by the Prosecutor - 2,037; on cases brought during the reporting period -1,944. (General Prosecutor's Office of the Republic of Kazakhstan, 2015).

Over the past 6 months of 2015 the General Prosecutor's Office of the Republic Kazakhstan has registered the following information on criminal cases: the number of crimes, whose criminal cases were in production during the reporting period -22,7011; the number of crimes whose cases were taken to court in the reporting period; the number of crimes registered during the reporting period - 211,715; the number of crimes whose cases were completed in the reporting period $-57,232$; the number of crimes, whose cases were taken to court in the reporting period $-28,391$; the number of crimes, whose criminal cases were terminated for non-rehabilitation reasons - 19,283; the number of crimes, whose criminal cases were terminated with the removal from the register $-4,556$; including the absence of elements and evidence of a crime (p.1.2 ch.1 art.37 of the Code of Criminal Procedure) - 4,552; on which the decisions to initiate proceedings were canceled by the Prosecutor - 2,101; on the cases brought during the reporting period -28,841 (General Prosecutor's Office of the Republic of Kazakhstan, 2015).

Table 1. Statistical data on the reported crimes and results of prosecution in 2010-2015.

\begin{tabular}{|c|c|c|c|c|c|c|c|c|c|c|c|}
\hline Year & \multicolumn{2}{|r|}{ Indicator } & 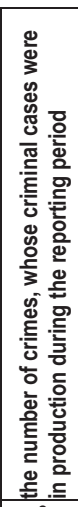 & 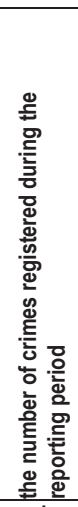 & 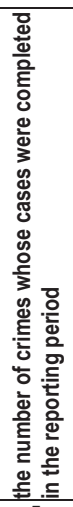 & 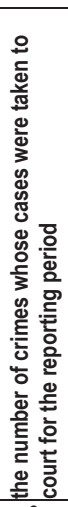 & 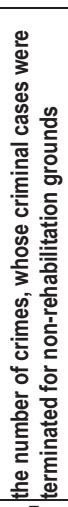 & 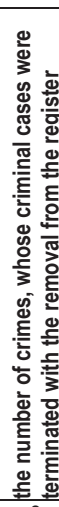 & 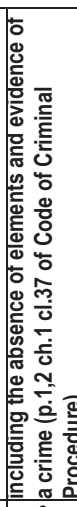 & 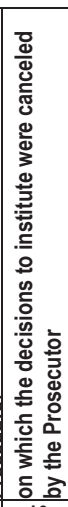 & 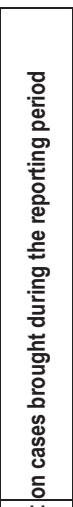 \\
\hline 1 & & 2 & 3 & 4 & 5 & 6 & 7 & 8 & 9 & 10 & 11 \\
\hline \multirow{6}{*}{ 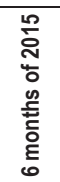 } & \multicolumn{2}{|r|}{ Total offences } & 227011 & 211715 & 57232 & 28391 & 19283 & 4556 & 4552 & 2101 & 28841 \\
\hline & \multirow{5}{*}{$\frac{\frac{1}{0}}{\frac{0}{3}}$} & minor offences & 45443 & 9250 & 3043 & 1644 & 1398 & 1 & 292 & 6207 & - \\
\hline & & crimes of average gravity & 137621 & 29391 & 11284 & 9361 & 1920 & 3 & 1023 & 18107 & - \\
\hline & & serious crimes & 18722 & 7267 & 7005 & 6938 & 66 & 1 & 745 & 262 & - \\
\hline & & extremely serious crimes & 1505 & 854 & 824 & 824 & - & - & 1 & 30 & - \\
\hline & & on the cases of the Road Police Department & 9964 & 9947 & 9478 & 5207 & 3165 & 2042 & - & - & 4271 \\
\hline
\end{tabular}




\begin{tabular}{|c|c|c|c|c|c|c|c|c|c|c|c|}
\hline \multirow{6}{*}{$\stackrel{+}{\stackrel{D}{n}}$} & \multicolumn{2}{|c|}{ Total offences } & 377330 & 341291 & 107304 & 59532 & 47772 & 33291 & 32798 & 2037 & 1944 \\
\hline & \multirow{5}{*}{$\frac{\bar{c}}{\frac{0}{3}}$} & minor offences & 41691 & 39608 & 16028 & 7134 & 8894 & 9500 & 9349 & 591 & 561 \\
\hline & & crimes of average gravity & 298439 & 271592 & 73482 & 34889 & 38593 & 19539 & 19398 & 1261 & 1200 \\
\hline & & serious crimes & 34569 & 27941 & 15786 & 15558 & 228 & 4064 & 3863 & 179 & 177 \\
\hline & & extremely serious crimes & 2631 & 2150 & 2008 & 1951 & 57 & 188 & 188 & 6 & 6 \\
\hline & & on the cases of the Road Police Department & 25158 & 24998 & 24957 & 16681 & 8276 & 11 & 11 & 0 & 0 \\
\hline \multirow{6}{*}{$\stackrel{m}{\sim}$} & \multicolumn{2}{|c|}{ Total offences } & 386710 & 359844 & 99471 & 65318 & 34153 & 18673 & 18346 & 2704 & 2631 \\
\hline & \multirow{5}{*}{ 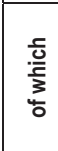 } & minor offences & 43818 & 43990 & 15204 & 7854 & 7350 & 5069 & 4976 & 759 & 738 \\
\hline & & \begin{tabular}{|c|} 
crimes of average gravity \\
\end{tabular} & 43818 & 43990 & 65329 & 38843 & 26486 & 10464 & 10408 & 1632 & 1588 \\
\hline & & serious crimes & 298889 & 279389 & 16459 & 16207 & 252 & 2990 & 2812 & 303 & 295 \\
\hline & & extremely serious crimes & 40681 & 33836 & 2479 & 2414 & 65 & 150 & 150 & 10 & 10 \\
\hline & & on the cases of the Road Police De & 3322 & 2629 & 21312 & 16329 & 4983 & 13 & 13 & 0 & 0 \\
\hline \multirow{6}{*}{ ণั) } & \multicolumn{2}{|c|}{ Total offences } & 306898 & 287681 & 84741 & 58607 & 26134 & 4756 & 4664 & 1633 & 1566 \\
\hline & \multirow{5}{*}{$\begin{array}{l}\frac{.}{0} \\
\frac{1}{3} \\
\frac{1}{6}\end{array}$} & minor offences & 23816 & 25460 & 9445 & 5113 & 4332 & 918 & 894 & 318 & 297 \\
\hline & & crimes of average gravity & 241112 & 228444 & 57141 & 35559 & 21582 & 2843 & 2830 & 999 & 970 \\
\hline & & serious crimes & 38142 & 30696 & 15243 & 15073 & 170 & 925 & 870 & 301 & 286 \\
\hline & & extremely serious crimes & 3828 & 3081 & 2912 & 2862 & 50 & 70 & 70 & 15 & 13 \\
\hline & & on the cases of the Road Police De & 14958 & 14797 & 14682 & 12996 & 1686 & 1 & 1 & & \\
\hline \multirow{6}{*}{ సे } & \multicolumn{2}{|c|}{ Total offences } & 204212 & 206801 & 73867 & 63893 & 9974 & 6666 & 6609 & 1299 & 1269 \\
\hline & \multirow{5}{*}{ 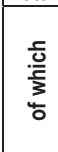 } & minor offences & 15333 & 17620 & 7283 & 5769 & 1514 & 2294 & 2277 & 262 & 257 \\
\hline & & crimes of a & 150680 & 156002 & 48240 & 40021 & 8219 & 3699 & 3687 & 768 & 750 \\
\hline & & \begin{tabular}{|l|l} 
seriol \\
\end{tabular} & 34100 & \begin{tabular}{|l|}
29657 \\
\end{tabular} & 15385 & 15204 & 181 & 586 & 558 & 255 & 248 \\
\hline & & extremely serious crimes & 4099 & 3522 & 2959 & 2899 & 60 & 87 & 87 & 14 & 14 \\
\hline & & on the cases of the Road Police & 14223 & 14129 & 14013 & 12831 & 1182 & 12 & 12 & 0 & 0 \\
\hline \multirow{6}{*}{ 운 } & \multirow{6}{*}{$\begin{array}{l}\frac{5}{0} \\
\frac{1}{3} \\
\frac{4}{0}\end{array}$} & Total offences & 132183 & 131896 & 76482 & 69700 & 6782 & 1406 & 1373 & 1031 & 978 \\
\hline & & minor offences & 13339 & 15969 & 8354 & 7091 & 1263 & 420 & 414 & 220 & 211 \\
\hline & & crimes of average gravity & 87908 & 90189 & 49458 & 44154 & 5304 & 605 & 590 & 579 & 548 \\
\hline & & serious crimes & 27309 & 22784 & 15847 & 15691 & 156 & 338 & 327 & 219 & 209 \\
\hline & & extremely serious crimes & 3627 & 2954 & 2823 & 2764 & 59 & 43 & 42 & 13 & 10 \\
\hline & & on the cases of the Road Police Department & 10750 & 10754 & 10623 & 10310 & 313 & 2 & 2 & 0 & 0 \\
\hline
\end{tabular}

The information presented indicates a significant increase in the number of criminal offences in all categories. Thus each year there is an increasing number of human rights violations in the Republic of Kazakhstan, while the increase in crime rates remains stable.

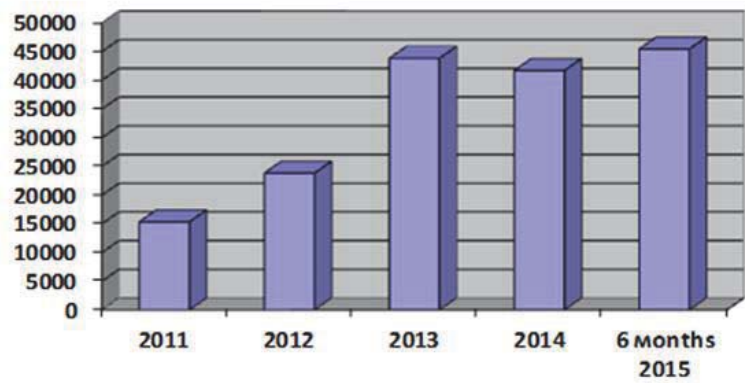

Chart 1. The number of not serious crimes, whose criminal cases were in production during the reporting period

Also, according to the information sources, quite a large number of authorized persons and civil servants were registered as offenders.

Overall, in 2014, 106,899 individuals were recorded as having committed different types of offences. It is sad that among them are persons who, by the duty of their service, are obliged to obey the law. They re civil servants $-1,670$, members of the armed forces of the Republic of Kazakhstan - 264, law enforcement personnel and judges - 666, judges who accounted for 7 people, MPs and candidates - 3, akims of urban, regional and district scale - 31 people (General Prosecutor's Office of the Republic of Kazakhstan, 2015).

It is particularly unfortunate that justice officials of the law enforcement system, "order guards" sanction violations of human rights and freedoms in law enforcement agencies (Baimoldina, 2008). 
The General Prosecutor's Office found that recently crimes have become more frequent in such spheres as: violation of copyright and related rights, and, in general, violation of intellectual property rights in the media, the Internet (Baimoldina, 2014); violations of intellectual property rights of Kazakhstan and foreign citizens, as a result of which the state loses a multi-million dollar revenue from their use (Baimoldina, 2014). At the same time, it is very difficult to identify the subjective element of these crimes, which means that many persons who have committed such crimes avoid responsibility and remain unpunished (Baimoldina, 2015).

Table 2. Information on persons performing public functions who have committed offences in 2014

\begin{tabular}{|c|c|c|}
\hline \multicolumn{2}{|l|}{ Indicator } & TOTAL \\
\hline \multicolumn{2}{|l|}{ A } & 1 \\
\hline \multicolumn{2}{|c|}{ Detection of offenders, total } & 106,899 \\
\hline \multicolumn{2}{|c|}{ persons performing public functions } & 1,670 \\
\hline \multirow{5}{*}{ 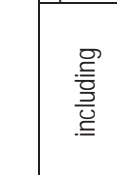 } & members of the armed forces of the Republic of Kazakhstan & 264 \\
\hline & law enforcement personnel & 666 \\
\hline & judges & 7 \\
\hline & MPs and candidates & 3 \\
\hline & akims & 31 \\
\hline
\end{tabular}

\subsection{Activities of prosecution authorities in terms of supervision of law enforcement agencies.}

Nowadays, the issues of coordinating law enforcement agencies by the prosecutor's office have become particularly important. The issues of coordinating the activities of law enforcement agencies in fighting corruption have gained particular relevance in recent years. Corruption is a complex socio-economic phenomenon that occurs at all stages of a country's history, in any state-organized society, differing only in size and forms of manifestation (Korzun, 2011).

Coordinating the activities of law enforcement agencies in this direction is an objectively necessary condition for fighting crime and administrative offences. The purposeful coordination can eliminate duplication and lack of cooperation; it presupposes that each of the law enforcement agencies will perform their duties actively, creatively and effectively. In this regard, it must be acknowledged that the lack of effectiveness of law enforcement agencies in combating offenses is explained, to a certain extent, by insufficient coordination in this sphere. This is caused by many commonly known factors related to the economic crisis, political instability and the lack of an adequate state mechanism of containing administrative offenses and crime (Yakubov, 2008).

Prosecutor's supervision applies to the execution of not only laws but also by-laws (Zuev, 2010).

The activities of the prosecutor's office in the Republic of Kazakhstan and the prosecutors' powers are determined by the Constitution of the Republic of Kazakhstan, the law of the Republic of Kazakhstan dated December 21, $1995 \mathrm{~N}$ 2709 "On the Prosecutor's Office" (on January 1, 2015 the law was revised), legislative acts, international treaties ratified by the Republic of Kazakhstan, as well as orders of the Republic's Prosecutor General. In terms of its structure, the Republic's law No. 2709 "on the Prosecutor's Office" dated December 21, 1995, consists of 12 chapters, 59 articles, in particular: General provisions (Chapter 1); Prosecution system and its organization (Chapter 2); Legal acts of the prosecutor's office (Chapter 3); Supervising the observance of human and civil rights and freedoms, interests of legal entities and the state (Chapter 4); Representing the state's interests in a court of law (Chapter 5); Supervising the lawfulness of investigative activities (Chapter 6); Supervising the lawfulness of investigation and inquiry (Chapter 7); Supervising the lawfulness of administrative proceedings (Chapter 8); Supervising the lawfulness of law enforcement proceedings (Chapter 9); Prosecution (Chapter 10); Cooperation with the competent agencies of foreign states (Chapter 10-1); Other spheres of activity of the prosecution authorities (Chapter. 10-2); Service in the prosecutor's office (Chapter. 11); Other issues of organization and activity of the prosecutor's office (Chapter 12) (the Republic's law "On the Prosecutor's Office", 1995).

According to art. 4 of the law, which reflects "the basic directions and content of the prosecutor's office activities", in order to ensure the supremacy of the Constitution and laws of the Republic of Kazakhstan, the protection of human and civil rights and freedoms, on behalf of the state, the prosecutor's office: shall exercise the highest supervision over exact and uniform application of the Constitution, the laws and decrees of the President of the Republic of Kazakhstan and other regulatory legal acts; identify and take steps to eliminate violations of the Constitution, laws, decrees of the President of the Republic of Kazakhstan and other regulatory legal acts; protest laws and other legal acts which contradict the Constitution and laws of the Republic of Kazakhstan; supervise the observance of human and civil rights 
and freedoms, the legitimate interests of legal entities and the state; oversee the lawfulness of the following activities: operational and investigative activities, pre-trial proceedings, administrative proceedings and law enforcement proceedings.

In addition, the prosecutor's office participates in legislation activities of public bodies within its competence; represents the state's interests in a court of law; conducts criminal prosecution in a manner and within the limits prescribed by the law; generates the state legal statistics in order to ensure the integrity, objectivity and sufficiency of statistical indicators, keeps special records, oversees the application of legislation in the field of legal statistics and special records; coordinates activities to ensure justice, public order and combating crime; oversees the observance of laws in the sphere of international legal cooperation. The law also states that the prosecutor's office performs other functions as defined by this law, other laws of the Republic of Kazakhstan and decrees of the President of the Republic of Kazakhstan" (the Republic's law" on Prosecutor's Office", 1995).

\subsection{Improvement of the legal norms regulating the activities of prosecution authorities.}

Analysis of the legal norms regulating the activities of prosecutors shows that many rules are conflicting and contradictory in certain parts. In this case, here is an example of conflicts regarding the norms of the law "on Prosecutor's Office".

Art. 5 of the law "On the Prosecutor's Office" governs the activities of prosecution authorities on the implementation of supreme supervision. In particular, it states that the supreme supervision over exact and uniform application of laws, decrees of the President of the Republic of Kazakhstan, other regulatory legal acts shall be effected by the inspections and (or) analysis of legality.

The prosecutor carries out the inspection of the legislation application within his competence after a ruling on running an inspection in the following cases: in connection with the request of the President of the Republic of Kazakhstan; statements, complaints, reports and other data on law violation; direct detection of law violation signs; a semi-annual consolidated schedule of inspections; a superior prosecutor's request or query. A prosecutor can also assign the inspection to a competent authority, who shall notify the Prosecutor of their findings within the statutory period or the period limited by the prosecutor. Inspection of legislation application is carried out within a month and is renewed only with the consent of the superior prosecutor.

All prosecutors' activities and acts of supervision lead to statutory consequences if they are committed in the manner and form prescribed by the law of the Republic of Kazakhstan on the Prosecutor's Office" and other regulatory legal acts (The Republic's law "On the Prosecutor's Office", 1995).

Analyzing the provisions of art. 7 of the law, which sets out the procedure for considering the applications concerning legislation violations and implementation of measures aimed at addressing the violations of human and civil rights and legitimate interests, legal entities and the state, the restoration of infringed rights, we can come to the conclusion that some of the provisions of this article need to be corrected.

Thus, for example, paragraph 2 of art. 7 states that "if a person is not able to exercise the protection of their rights on account of their physical, mental or other deficiencies, the prosecutor is obliged to take the necessary measures to ensure this (the Republic's law "On the Prosecutor's Office", 1995).

In this case, the word "shortcomings" seems a very narrow expression which can be interpreted by the authorized persons in two ways, at their own discretion, without covering certain life circumstances, in which the protection of human rights is complicated by different circumstances not depending on the person or the citizen, bordering on or being "force majeure". For example, these circumstances include the following: non-flying weather, a natural disaster, an emergency, a severe disease and a number of others, i.e. when a person cannot personally take part in the protection of their rights in the judicial process, criminal proceedings and other conditions. In some cases, the word "shortcomings" could be perceived as impairing human dignity, inferiority in something that affects a person's self-esteem, humiliation of their feelings, the understatement of their capacities and abilities, etc.

Proposal 1: In connection with the above mentioned, we consider it appropriate to add the word "circumstances" to the paragraph and reword the paragraph so that it reads as follows:

"2. If persons are unable to defend their rights due to physical, mental or other deficiencies and circumstances, the prosecutor is obliged to take the necessary measures to ensure this".

Furthermore, in accordance with paragraph 3 of this article, in the manner prescribed by the law, the prosecution authorities take measures to prosecute officials who fail in their duties to protect human rights and freedoms, interests of legal entities and the state. 
In this case, the anonymous statements, as specified in paragraph 4, are not checked by the prosecutor's office, but the prosecutor has the right not to disclose the source of information in the citizen's best interests (the Republic's law "On Prosecutor's Office", 1995).

Studying the norms of art. 8 of the law under consideration, which sets out the procedure for the review of actions and acts of the prosecutor, we can come to a conclusion that the procedure for appealing the prosecutor's acts needs to be reviewed.

Thus, for example, p. 1 of this law provides that actions and acts of the prosecutor may be appealed to a higher prosecutor or to the court. In this case, appealing the prosecutor's demands and acts does not suspend their execution.

In our view, in this case it is important to have an objective approach in terms of legality of the prosecutor's demands and acts. It is still possible that under certain circumstances, when not all facts of the case are known, the prosecutor's acts may contain a legal mistake and violate the rights of citizens, legal entities, and therefore, be contrary to the constitutional norms of the Republic of Kazakhstan.

In our opinion, in order to avoid possible violations of human rights guaranteed by the Constitution, it would be advisable to suspend them pending a superior prosecutor's decision.

Proposal 2: in connection with the above, we consider it appropriate to make amendments to this paragraph so that it reads as follows:

"1. The prosecutor's actions and acts may be appealed to a higher prosecutor or to the court. Appealing the prosecutor's demands and acts suspends their execution pending a superior prosecutor's decision.

Also, in some proposals there are missing commas, which is unacceptable for regulatory acts of such level.

These comments are debatable; the introduction of the proposed amendments is advisory and thus non-binding (Baimoldina, 2014).

\subsection{Specific features of activities of prosecution authorities in foreign countries}

Prosecution authorities in different countries occupy a legal niche which is far from being identical. Analysis of foreign legislation allows us to single out four groups of unitary states:

1) countries where the prosecutor's office is part of the Ministry of Justice (France, Poland, Japan);

2) countries where the prosecutor's office is included in the structure of the judiciary system (the magistracy) and is located with the courts (Spain, Italy);

3) countries where there is no prosecutor's office (United Kingdom);

4) countries where the prosecutor's office is singled out into an independent system and reports to the Parliament or the President (China, Democratic People's Republic of Korea and some CIS countries).

In the CIS countries, in one case, the prosecutor's office occupies a certain place in the judicial system (for example, in Azerbaijan, Georgia, Latvia, Lithuania), in another case (for example, the Russian Federation) the prosecutor's office is given an independent role, similar to the one in the former USSR's state legal system. The competence and specific tasks of the prosecutor's office, priorities in its activities are also defined differently (Kopabayev, 2002).

The Constitution of the Republic of Kazakhstan leaves open the question of the place of the prosecutor's office in the government system. The current law on the prosecutor's office does not fill this gap in full. The existing conceptual model does not provide a full and clear answer either to the theoretical or to numerous practical questions. Moreover, even prosecutors practice different approaches to similar cases. This is understandable, since today we are facing profound and rapid changes: renunciation of old stereotypes and search for new ones, reinterpretation of history and criticism of classical authorities.

It is crucial to exactly designate the place of the prosecutor's office in the system of state legal institutions of the Republic of Kazakhstan in order to determine the essence of the prosecution system, the functions of the prosecutor's office, its legal status, organizational structure, forms and methods of activity, the legal nature of the prosecutor's legal acts. The powers of the prosecutor's office are unreasonably expanded by errors in establishing its place, irrespective of whether they involve belittling the role of the prosecutor's office, or vice versa. These mistakes are fraught with dangerous consequences for the functioning of the law enforcement system and for society as a whole. It is in this area that the theoretical principles must be based in the first place on deep knowledge of social practice, exclude the possibility of applying the method of trial and error, the commitment to which is demonstrated by some individual active reformers. 
It would seem that a solution to the question of the place of the prosecutor's office in the system of state legal institutions arises from the general concept of Kazakhstan statehood mechanism, enshrined in the Constitution of 1995 as well as its underlying principles of power separation. Separation of powers in Kazakhstan's state mechanism does not mean understanding the prosecution authority as a separate branch of power along with the legislative, executive or judicial. However, we cannot either think that the principle of power separation leaves no room for independent supervisory role of the prosecution system, or conclude that it is necessary to dissolve the prosecution authority in the judicial system or in the structure of the executive power, in particular, by transferring it to the Ministry of Justice of the Republic of Kazakhstan.

The fundamental branches of power - legislative, executive and judicial - represent single state power and its separation, functionally autonomous legal institutions. Their existence is determined by the real needs of the state legal life, the need for democratic control and controlling any of the major branches of power. On the other hand, it is important that these institutions should fit into the framework of a democratic state structure and contribute to the balance of the fundamental branches of power.

In modern conditions, the prosecutor's office carries out the functions of an element of the check and balance system. It establishes and takes steps to eliminate any violations of laws, no matter where they come from. At the same time, the prosecutor's office with its entire activity fosters cooperation between separated branches of power, their cumulative coherent functioning as a unified state power. All of them are interested in maintaining and strengthening justice, which the prosecutor's office is intended to provide. Without justice there cannot be either a strong power, which successfully performs its functions, or a state which strives to become legal. The increasing role of the prosecutor's office in the formation and development of a democratic and legal state in Kazakhstan is determined by the fact that it represents a necessary and reliably working element of the emerging system of providing separation and interaction of the branches of power. All the prosecutor's office functions should be specifically aimed at this.

Let's turn to foreign practice. There are different opinions on the place of the prosecutor's office in the Russian legal science.

The first opinion is that the prosecutor's office is part of the legislative power on whose behalf it oversees law enforcement at all levels (Berkovich, 1998).

The second opinion is that the prosecutor's office is included in the system of the judiciary power as the criminal prosecution agency (Vitruk, 1993).

The third opinion lies in that the prosecutor's office is limited only to the function of the executive branch of power within the Ministry of Justice (Koberskiy, 2000).

The fourth opinion is about the concept of two types of prosecutor's office. Its author, Professor of Kiev University, M.M. Mikheenko proposes to establish two subsystems of the prosecutor's office. One of them is general supervisory prosecution within the parliament, which will perform the monitoring function of the legislature; the other one is judiciary prosecution, headed by the Minister of Justice. This prosecution authority will initiate criminal proceedings, prosecute a case in a court of law, oversee the observance of laws by bodies of inquiry and preliminary investigation, as well as by the bodies executing sentences and other court decisions (Baskov, 1986).

Regarding the powers of the prosecutor's office, for example, V. Bessarabov believes that the prosecutor's supervision must be reduced to a minimum. At the same time, he brings forward arguments about "miserable" effectiveness of supervision over law enforcement. In connection with this, by minimizing the supervision, it is necessary to release prosecution resources in order to solve the main task of the prosecution authorities - fighting against crime (Bessarabov, 2002). There are other concepts which can be considered in other studies.

\section{Conclusion}

The implementation of checks or realization of prosecutors' other powers is often determined by political reasons. This is facilitated by the possibility of holding such checks not only on applications, complaints, reports and other information on violations of law or by directly identifying their characteristics, but also on the president's initiative or the superior prosecutor's orders and requests. Obviously, there may be a superior prosecutor's orders and requests as the basis for carrying out the checks, but this can happen only if there are justified complaints about the failure to take appropriate steps by the subordinate prosecutor or other officials.

The law "On Private Entrepreneurship" (Law of the Republic of Kazakhstan, 2006) adopted on January 31, 2006 regulated in detail the procedure for the organization and holding of private enterprise inspections by different departments. It also clearly defined the types and the list of bodies of state control and supervision. This is largely due to the fact that the checks by the tax inspection, fire protection, sanitary, environmental and other services are regulated by 
numerous departmental policies, which violate the rights of entrepreneurs and cause a growth of corruption in these bodies. The adoption of this law is intended to protect businesses from unreasonable checks and unlawful actions by relevant state authorities and officials. However, the provisions of the law do not apply to prosecutor's checks.

Full observance of human rights and the prosecutor's supervision of this in the Republic of Kazakhstan require a thorough revision of the standards.

\section{Acknowledgements}

The author of the article is grateful to the outstanding lawyers of the Russian Federation and the Republic of Kazakhstan, in particular to the associate professor of criminal law department of L.N. Gumilev Eurasian National University and candidate of legal sciences Baimoldina Svetlana Malikovna for providing materials and rendering methodological assistance in the preparation of this article.

\section{References}

Baskov, V.I. (1986). Prokurorskiy nadzor za ispolneniyem zakonov pri rassmotrenii ugolovnykh del v sudakh. [Prosecutor's supervision of law implementation in criminal cases in courts]. - Moscow: Judicial literature. [in Russian]

Baimoldina, S.M. (2008). Narusheniya prav i svobod cheloveka v sisteme pravookhranitel'nykh organov. Pravo i gosudarstvo. [Violations of human rights and freedoms in law enforcement system. Law and State]. - Astana: Kazakh State Law University. (pp. 133 138). [in Russian].

Baimoldina S.M. (2014). Concept of legal protection of intellectual property rights. International educational technology conference. Proceeding book. September 3-5. Chicago. (pp. 212-219).

Baimoldina, S.M. (2014). Mechanism of the Regulation of Intellectual Property Rights in Mass-Media and Internet. Proceedings Book. ITICAM 2014, International Trends and Issues in Communication Media Conference. February 5-7. Dubai. (pp. 97-100).

Baimoldina, S.M. (2015). Sub'yektivnaya storona narusheniya prav intellektual'noy sobstvennosti. Ugolovnoye pravo: strategiya razvitiya $\checkmark \mathrm{XXI}$ veke: materialy mezhdunarodnoy nauchno-prakticheskoy konferentsii. [The subjective aspect of intellectual property infringement. Criminal Law: Development strategy in the XXI century: Proceedings of the international research and practice conference]. Kutafin Moscow State Law University. - Moscow. (pp.538-541). [in Russian]

Baimoldina, S.M. (2014). Pravovoye regulirovaniye deyatel'nosti prokurora v Respublike Kazakhstan. [Legal regulation of Prosecutor's activity in Republic of Kazakhstan] // Bulletin of Gumilyov Eurasian National University: Judicial series. [in Russian].

Berkovich, Y.F. (1998.) Prokurorskiy nadzor za ispolneniyem zakonov. [Prosecutor's supervision of the implementation of laws]. MOSCOW:Expert bureau. [in Russian].

Bessarabov, V.G. (2002). Prokuratura kak institut gosudarstvennoy vlasti v Rossiyskoy Federatsii. [Public Prosecution as an institution of state power in Russian Federation] // The place and the function of public prosecution in the state bodies of Republic of Kazakhstan and its function in protection of human and civil rights. International conference information package. - Almaty. (pp.20-29). [in Russian]

Dzhafarov, A.M. (2008). Mezhdunarodno-pravovyye osnovy reformirovaniya organov prokuratury Azerbaydzhanskoy Respubliki. [The international framework of prosecution reform of the Azerbaijan Republic]: Abstract from candidate dissertation in Law. Moscow. (P.50). [in Russian]

Gonibesov, D.A. (2007). Nadzor prokuratury za soblyudeniyem prav i svobod cheloveka i grazhdanina. [Prosecutor's supervision of compliance with the rights and freedoms of man and citizen]: Abstract from candidate dissertation in Law. - Yekaterinburg. (P.30) [in Russian]

General Prosecutor's Office of the Republic of Kazakhstan, (2015). Komitet pravovoy statistiki pri General'noy prokurature Respubliki Kazakhstan. [Committee for Legal statistics of the Prosecutor's Office of the Republic of Kazakhstan] www. pravstat.kz

Karpov, N. N. (2012). Teoreticheskiye i prikladnyye problemy deyatel'nosti prokuratury po obespecheniyu zakonnosti $\vee$ sfere prokhozhdeniya voyennoy sluzhby. [Theoretical and applied problems of Prosecutor's activity to ensure legality provision in the sphere of military service.]: Abstract from candidate dissertation in Law. - Moscow. (P.50). [in Russian]

Kobersky, Y.P. (2000). V interesakh obespecheniya yedinogo pravovogo prostranstva [For the benefit of common legal framework.] /I Bulletin of Justice of the Russian Federation. No.12. (pp.45-49). [in Russian]

Constitution of the Republic of Kazakhstan, adopted on the republican plebiscite on the 30th of August, 1995.

Korzun, I.G. (2011). Koordinatsiya prokuraturoy deyatel'nosti pravookhranitel'nykh organov po protivodeystviyu korruptsii [Coordination of prosecutor's activity of law enforcement authorities in combating corruption]: Abstract from candidate dissertation in Law. Moscow.

Safonova, T.Y. (2011). Konstitutsionno-pravovoye regulirovaniye deyatel'nosti prokuratury Rossii kak gosudarstvennogo organa s osobym pravovym statusom. [Constitutional and legal regulation of the Russian Prosecutor's activity as a body with a special] Abstract from candidate dissertation in Law. - Yelets (p. 30). [in Russian]

Sharov, R.V. (2006). Nadzor prokuratury za ispolneniyem zakonov, ogranichivayushchikh prava i svobody cheloveka i grazhdanina. [Prosecutors supervision of the laws execution, which restricts the fulfillment]. Abstract from candidate dissertation in Law. Moscow. [in Russian] 
Solomatina, E.A. (2004). Teoretiko-pravovyye osnovy kontrolya zakonodatel'noy vlasti za deyatel'nost'yu pravookhranitel'nykh organov. [Theoretical and legal basis for controlling by the legislative power of law enforcement activity.]: Abstract from candidate dissertation in Law. - Moscow [in Russian].

The Law of the Republic of Kazakhstan "On private enterprise" dated January, 31st, 2006. №124-III /I Kazakhskaya Pravda [Kazakhstan's truth]. - 2006, February, $7^{\text {th }}$.

The Law of the Republic of Kazakhstan dated December 24, 1995. No.2709 "On Public Prosecution". [in Russian]

Turygin, Y. N. (2012). Vzaimodeystviye prokuratury Rossiyskoy Federatsii i nepravitel'stvennykh pravozashchitnykh organizatsiy po zashchite prav i svobod cheloveka i grazhdanina. [Cooperation between Prosecutor's Office of the Russian Federation and nongovernmental organization on protection of human and civil rights and freedoms.]: Abstract from candidate dissertation in Law. Moscow. (P.30). [in Russian]

Uryvaev, A.V. (2009). Prokuratura Rossiyskoy Federatsii v mekhanizme zashchity konstitutsionnykh prav i svobod cheloveka i grazhdanina. [Public Prosecution of the Russian Federation in protection mechanism of constitutional human and civil rights and freedom.]: Abstract from candidate dissertation in Law. - Saratov, (P. 30). [in Russian].

Utibaev, G.K. (2007). Teoretiko-prikladnyye problemy koordinatsii deyatel'nosti pravookhranitel'nykh organov po preduprezhdeniyu prestupleniy. [Theoretical and applied coordination problems of law enforcement on crime prevention]: Abstract from doctoral dissertation in Law, Kazakh State Law University. - Astana. [in Russian].

Vitruk, N.V. (1993). Zakonnost': ponyatiye, zashchita i obespecheniye: Obshchaya teoriya prava [Legality: the concept, protection and provision: General Theory of Law.] Course of lectures. - Nizhny Novgorod. [in Russian]

Yakubov S. V. (2008). Administrativno-pravovaya sfera deyatel'nosti organov prokuratury: koordinatsiya protivodeystviya pravonarusheniyam. [Administrative and legal activity domain of Prosecution authorities: coordination of offenses counteraction]: Abstract from candidate dissertation in Law. - Moscow. [in Russian].

Zuev, S.V. (2010). Teoreticheskiye i prikladnyye problemy sovershenstvovaniya ugolovnogo presledovaniya po delam o prestupleniyakh, sovershayemykh organizovannymi gruppami i prestupnymi soobshchestvami [Theoretical and applied problems of criminal prosecution improvement of cases committed by organized criminal groups and communities]: Abstract from candidate dissertation in Law - Moscow. [in Russian] 